\title{
Adopsi Inovasi Program Keluarga Berencana oleh Akseptor dari Komunitas Adat Terpencil Baduy di Kecamatan Leuwidamar Kabupaten Lebak
}

\author{
The Adoption of Family Planning Innovation Program by Acceptorrs from Remote Indigenous \\ Communities of Baduy in the Leuwidamar, Lebak District
}

\author{
Ahmad Sihabudin $^{1}$, Idi Dimyati ${ }^{1}$, Burhanuddin Mujtaba ${ }^{1}$ \\ ${ }^{1}$ Departemen Ilmu Komunikasi FISIP Untirta - Serang
}

\begin{abstract}
There was a trend of acceptors' increasing on Family Planning (KB) on Remote Indigenous Community (KAT) in Baduy at Leuwidamar of Lebak District in Banten. Data showed in 2006 the KB acceptors in Outer Baduy amounted to 647, participants per month in February 2014 in Outer Baduy was 1403 participants, and acceptor in Baduy was 16 participants. Moreover there are variations in which the contraception is used, earlier the KAT Baduy accepted the concept of using the implant. Therefore this research was designed to determine the type and characteristics of innovation in Family Planning programme (KB), a channel or media in the dissemination of family planning; and which factors that adopters' characteristics would influence the acceptance of family planning. The method used was explanation survey, an analysis of using frequency distribution, and to determine the relationship between variables is using Spearman correlation analysis. The results showed that the respondents's age varied from 13 to 45 years, with most are aged 18-25 years. Dominantly, they have 2 until 4 children. Their occupation mostly are cloth weavers. The distant from their house to the health clinic mostly is within two hours walk. Majority of women respondents are using injection as a contraception in Outer Baduy. They have been an acceptor for 1-3 years; 7-9 years and also more than 10 years. They decided to get along with the KB programme within 6 months and they choose with injectables at first. The reason of using family planning is having a gap in conceiving children. It is requuired a strategic development so that the changes planned can be done to fulfilled the need of Family Planning in the ingenious community of Baduy. There is a positive correlation between the characteristics of acceptors with the effectiveness of the acceptance of innovation. The correlation between the effectiveness and the social system of innovation is negative or almost with no influence. The correlation between the type of communication channels with the effectiveness of the reception innovation have a strong relationship.
\end{abstract}

Keywords: baduy, characteristics of acceptors; innovation in Family Planning

\begin{abstract}
Abstrak
Adanya tren peningkatan akseptor Keluarga Berencana (KB) pada Komunitas Adat Terpencil (KAT) Baduy Kecamatan Leuwidamar Kabupaten Lebak Banten. Data menunjukkan Tahun 2006 Akseptor KB di Baduy Luar berjumlah 647 peserta, per bulan Pebruari 2014 jumlah akseptor KB Baduy Luar 1403 peserta, dan akseptor di Baduy dalam 16 peserta. Selain itu ada variasi penggunaan alat kontrasepsi yang dipakai, pada masa awal KAT Baduy menerima konsep KB kebanyakan mereka menggunakan implant. Dari gejala tersebut penelitian ini dirancang dengan tujuan untuk mengetahui jenis dan ciri inovasi KB, saluran atau media apa dalam penyebaran KB; faktor-faktor karakteristik adopter apa saja yang mempengaruhi penerimaan KB. Metode penelitian yang digunakan adalah Survai explanasi. Jumlah sampel penelitian sebanyak 100 orang. analisis dengan menggunakan distribusi frekuensi, dan untuk mengetahui hubungan antar peubah dilakukan analisis korelasi Spearman. Hasil penelitian menunjukkan usia responden sebenarnya relatif terdistribusi mulai umur 13 sampai 45 tahun, paling banyak adalah usia 18-25 tahun. Jumlah putra yang dimiliki paling dominan antara 2 anak dan 4 anak. Jenis Pekerjaan responden sebagian besar adalah penenun kain. Jarak rumah tempat tinggal responden ke klinik kesehatan sebagian besar berjarak 2 jam perjalanan kaki ke klinik. Jenis alat KB (kontrasepsi) mayoritas perempuan Baduy Luar menggunakan suntik. Masa lama telah ber-KB, sebagian besar 1-3 Tahun, ada juga sudah 7-9 tahun dan yang lebih dari 10 tahun ber-KB ternayata cukup besar. Lama memutuskan ikut KB sebagian besar yakni 6 bulan. Saat awal ber KB mayoritas alat kontrasepsi yang merteka pilih dengan cara suntik. Alasan ber-KB jawaban yang paling banyak disebut adalah demi menjarangkan anak. Diperlukan pengembangan strategi agar perubahan terencana dapat dilakukan untuk lebih memenuhi kebutuhan akan keluarga berencana masyarakat adat Baduy. Terdapat korelasi yang positif antara karakteristik akseptor KB dengan efektifitas penerimaan inovasi. Korelasi antara sistem sosial dengan efektifitas penerimaan inovasi bernilai negatif atau hampir tanpa pengaruh. Korelasi antara jenis saluran komunikasi dengan efektifitas penerimaan inovasi mempunyai hubungan yang cukup kuat.
\end{abstract}

Kata kunci: baduy, karakteristik akseptor; inovasi Keluarga Berencana

\footnotetext{
${ }^{1}$ Korespondensi penulis

E-mail: ididimyati@gmail.com
} 


\section{Pendahuluan}

Sebutan "Orang Baduy" atau "Urang Baduy" yang digunakan untuk kelompok masyarakat ini bukan berasal dari mereka sendiri. Penduduk wilayah Banten Selatan yang sudah beragama Islam, biasa menyebut masyarakat yang suka berpindah-pindah seperti halnya orang Badawi di Arab, dengan sebutan "Baduy". Orang-orang Belanda seperti Hoevell, Jacobs, Meijer, Penning, Pleyte, Trcht, dan Geise menyebut mereka badoe $i$, badoej, badoewi, dan orang kanekes seperti dikemukakan dalam laporanlaporannya. Sekitar tahun1980-an, ketika KTP (KartuTandaPenduduk) diberlakukan di sini, hampir tidak ada yang menolak dengan sebutan Orang Baduy. Walaupun, sebutan diri yang biasa mereka gunakan adalah Urang Kanekes, Urang Rawayan, Urang Tangtu (Baduy Dalam) dan Urang panamping (BaduyLuar). Nama"Baduy" mungkin diambil dari nama sungai Cibaduy dan nama gunung Baduy yang kebetulan berada di wilayah Baduy (Garna, 1994).

Apabila kita menanyakan mengenai asal usul orang Baduy, jawaban yang akan diperoleh adalah mereka keturunan dari Batara Cikal, salah satu dari tujuh dewa atau batara yang diutus ke bumi. Asal usul tersebut sering pula dihubungkan dengan Nabi Adam sebagai nenek moyang pertama. Menurut kepercayaan mereka, Adam dan keturunannya, termasuk warga Baduy mempunyai tugas bertapa atau asketik (mandita) untuk menjaga harmoni dunia (Garna, 1993).

Sumber lain menyebutkan masyarakat Baduy dikaitkan dengan Kerajaan Sunda atau yang lazim disebut sebagai Kerajaan Pajajaran, pada abad 15 dan 16,atau kurang lebih enam ratus tahun yang lalu. Wilayah Banten pada waktu itu merupakan bagian penting dari Kerajaan Pajajaran, yang berpusat di Pakuan (wilayah Bogor sekarang). Banten merupakan pelabuhan dagang yang cukup besar. Sungai Ciujung dapat dilayari berbagai jenis perahu, dan ramai digunakan untuk pengangkutan hasil bumi dari wilayah pedalaman. Dengan demikian penguasa wilayah tersebut,yang disebut sebagai Pangeran Pucuk Umun menganggap bahwa kelestarian sungai perlu dipertahankan. Untuk itu diperintahkanlah sepasukan tentara kerajaan yang sangat terlatih untuk menjaga dan mengelola kawasan berhutan lebat dan berbukit di wilayah Gunung Kendeng tersebut. Keberadaan pasukan dengan tugasnya yang khusus tersebut tampaknya menjadi cikal bakal Masyarakat Baduy yang sampai sekarang masih mendiami wilayah hulu Sungai Ciujung di Gunung Kendeng tersebut (Adimihardja, 2000:47-59). Perbedaan pendapat tersebut membawa kepada dugaan bahwa pada masa yang lalu, identitas dan kesejarahan mereka sengaja ditutup, yang mungkin adalah untuk melindungi komunitas Baduy sendiri dari serangan musuh-musuh Pajajaran.

Berdasarkan perhitungan, populasi penduduk umumnya didominasi oleh penduduk Baduy Luar. Penduduk Baduy Dalam menurut catatan tersebut berjumlah 1208 orang, terdiri atas 1528 orang warga Cikeusik, 141 orang warga Cikartawana, dan 539 orang warga Cibeo. Hal ini berarti penduduk Baduy Dalam hanya 9,6 persen saja dari keseluruhan penduduk Baduy. Laju pertambahan penduduk, dan pemekaran atau bertambahnya jumlah perkampungan di Baduy Luar secara keseluruhan, berdasarkan data yang diperoleh dari profil desa Kanekes, dan Pusat Kesehatan Masyarakat (Puskesmas) Leuwidamar, jumlah data penduduk dan penyebaran pada setiap Kampung baik di Baduy Luar maupun Baduy Dalam sampai dengan Tahun 2015. Saat ini Jumlah Kampung Baduy Luar 61 kampung, dan 3 Kampung Baduy Dalam (Cibeo, Cikartawana, danCikeusik), dengan jumlah kepala keluarga 3.395, terdiri dari pria 5.870 orang, dan wanita 5.750 orang, jumlah keseluruhan penduduk baduy luar dan baduy dalam 11.620 orang (Profil Desa Kanekes, 2015).

Gejala pertumbuhan penduduk cukup menarik perhatian, naik turun pertumbuhan penduduk kemungkinan besar diakibatkan oleh adanya perkawinan yang terlalu dekat diantara kelompok mereka. Dugaan tersebut didasarkan atas tidak ada laporan yang menyatakan terjadinya bencana alam, kelaparan, atau ledakanpenyakit.

Penelitian terhadap masyarakat Baduy sudah banyak dilakukan. Sejak pada masa kolonial Belanda riset Antropologi sosial masyarakat Baduy sudah dilakukan, namun penelitian di Baduy yang fokus penulisannya pada cara hidup ber Keluarga Berencana (KB) di Baduy masih jarang dilakukan. Fokus penelitian, dilakukan berdasarkan data catatan Bidan Eros Rosita, paramedis yang bertugas di Desa Kanekes (Bidan yang menangani kesehatan Komunitas Adat Baduy), Kecamatan Leuwidamar, Kabupaten Lebak, dan data dari Puskesmas Pembantu Ciboleger. Adanya trend kenaikan jumlah peserta KB pada KAT Baduy inilah yang menjadi pendorong utama penelitian ini. Beranghkat dari data kenaikan 
yang terus menerus itulah penelitian dilakukan, karena bila KB sudah menjadi kebutuhan KAT Baduy, ini mengindikasikan perlu adanya bentuk layanan kesehatan yang lebih intensif diberikan pada KAT Baduy.

Selain itu keragaman alat kontrasepsi yang digunakan, seperti pada Tabel 1 di bawah, dan adanya trend peningkatan peserta $\mathrm{KB}$ di Baduy, mendorong untuk mengetahui dan memahami gejala tersebut dalam konteks penerimaan inovasi, khususnya pada hubungan antara karakteristik akseptor dengan penerimaan cara hidup dan konsep keluarga berencana yang terjadi di KAT Baduy.

Tabel 1. Keikutsertaan KB Warga Baduy Luar dan Baduy Dalam

\begin{tabular}{lll}
\hline $\begin{array}{c}\text { Alat } \\
\text { Kontrasepsi }\end{array}$ & $\begin{array}{c}\text { Akse ptor Baduy } \\
\text { Luar }\end{array}$ & \multicolumn{1}{c}{$\begin{array}{c}\text { Aks eptor Baduy } \\
\text { Dalam }\end{array}$} \\
\hline Implant & 112 orang & - \\
IUD & 6 orang & 1 orang \\
Suntik & 1205 orang & 15 orang \\
Pil & 80 orang & - \\
Jumlah & 1403 orang & 16 orang \\
\hline
\end{tabular}

Sumber: Bidan Rosita/Puskesmas Pembantu Ciboleger (2015).

Mengingat sifat dan karakter masyarakat ini termasuk yang menutup diri terhadap hal-hal yang berasal dari luar komunitasnya. Meskipun secara umum dan pada hakikatnya masyarakat manapun membutuhkan perubahan dalam pengertian perubahan kehidupan yang lebih baik, baik pengetahuan, keterampilan dan sikap mental, khususnya dalam menerima konsep hidup Keluarga Berencana.

Menurut Adimihardja (2007:11) komunitas adat sebagai bagian dari masyarakat Indonesia adalah kelompok masyarakat yang terisolasi, baik secara fisik, geografi, maupun sosial budaya. Sebagian besar komunitas ini bertempat tinggal di daerah terpencil dan sulit dijangkau. Pranata sosial dalam komunitas adat ini umumnya bertumpu pada hubungan kekerabatan yang sangat terbatas dan homogen. Kehidupan mereka sehari-hari masih didasarkan pada interaksi tradisional yang bersifat biologis, hubungan darah dan ikatan tali perkawinan.

Pengertian KAT dalam surat Keputusan Presiden No 111 tahun 1999 adalah kelompok sosial budaya yang bersifat lokal dan terpencar serta kurang atau belum terlibat dalam jaringan dan pelayanan baik sosial, ekonomi maupun politik. Berdasarkan pengertian tersebut, maka kelompok masyarakat tertentu dapat dikategorikan sebagai Komunitas Adat Terpencil jika terdapat ciri-ciri umum yang berlaku universal sebagai berikut: (1) Berbentuk komunitas kecil, tertutup dan homogen. (2) Pranata sosial bertumpu pada hubungan kekerabatan. (3) Pada umumnya lokasinya terpencil secara geografis dan relatif sulit dijangkau. (4) Pada umumnya masih hidup dengan sistem ekonomi sub-sistem. (5) Peralatan teknologinya sederhana, sangat tradisionil. (6) Ketergantungan pada lingkungan hidup dan sumber daya alam setempat relatif tinggi. (7) Akses terhadap pelayanan sosial, ekonomi, dan politik terbatas.

Misi pemberdayaan komunitas adat terpencil adalah meningkatkan harkat dan martabat Komunitas Adat Terpencil (KAT), meningkatkan kualitas hidup Komunitas Adat Terpencil, memperkuat pranata dalam jaringan sosial, mengembangkan sistem kehidupan dan penghidupan yang berlaku pada KAT, dan meningkatkan peranserta dan tanggung jawab sosial masyarakat dalam proses pemberdayaan KAT.

Berdasarkan latar belakang masalah di atas, maka terdapat dua pertanyaan penelitian yang akan dikaji yaitu: (1) bagaimana karakteristik akseptor KB di KAT Baduy, dan (2) bagaimana hubungan karakteristik dengan penerimaan inovasi KB di KAT Baduy.

Tujuan penelitian ini adalah: menganalaisis karakteristik akseptor $\mathrm{KB}$ di KAT Baduy, dan (2) menganalisis hubungan karateristik dengan penerimaan inovasi KB di KAT Baduy.

Mengacu pada masalah penelitian dan tujuan penelitian, untuk mengetahui karakteristik akseptor dan hubungannya dengan penerimaan inovasi ciri inovasi KB yang mudah diterima. Sebagai landasan teori digunakan Teori difusi inovasi yag di kemukakan Everett M. Rogers, dan F. Floyd Shoemaker (1971).

Teori Difusi Inovasi pada dasarnya menjelaskan proses bagaimana suatu inovasi disampaikan (dikomunikasikan) melalui saluransaluran tertentu sepanjang waktu kepada sekelompok anggota dari sistem sosial. Hal tersebut sejalan dengan pengertian difusi dari Rogers (1971), yaitu " $a$ s the process by which an innovationis communicated throughcertain channelsover timeamong the members of a social system. " Lebih jauh dijelaskan bahwa difusi adalah suatu bentuk komunikasiyang bersifat 
khusus berkaitan dengan penyebaranan pesan-pesan yang berupa gagasan baru, atau dalam istilah Rogers dan Shoemaker (1971) difusi menyangkut "which is the spread of a new idea from its source of invention or creation to its ultimate users or adopters. "

Salah satu perspektif komunikasi yang berbicara mengenai penyebaran hal baru adalah Diffusion of indovations Model (model difusi inovasi). Model difusi banyak digunakan dalam komunikasi pembangunan,terutamadi negara-negara berkembang termasuk di Indonesia. Menurut Erlina dan Kurniasari (2006), deseminasi informasi kepada masyarakat pedesaan dilaksanakan melalui berbagai macam media komunikasi. Roger dan Shoemaker berpendapat, dalam riset difusi biasanya lebih memusatkan perhatian padaterjadinya perubahan tingkah laku yang tampak (over behavior), yaitu menerima atau menolak ide(budaya) baru daripada hanya sekedar pengetahuan dan sikap saja. Difusi adalah suatu tipe khusus komunikasi (Rogers dan Shoemaker,1971:13).

Sesuai dengan pemikiran Rogers dan Shoemaker (1971), dalam proses difusi inovasi terdapat 4 (empat)elemenpokok, yaitu: (1) Inovasi; gagasan, tindakan, atau barang yang dianggap baru oleh seseorang. Dalam hal ini, kebaruan inovasi diukur secara subjektif menurut pandangan individu yang menerimanya. Jika suatu ide dianggap baru oleh seseorang maka ia adalah inovasi untuk orang itu. Konsep "baru" dalam ide yang inovatif tidak harus baru sama sekali. (2) Saluran komunikasi; "alate untuk menyampaikan pesan-pesan inovasi dari sumber kepada penerima. Dalam memilih saluran komunikasi, sumber paling tidak perlu memperhatikan (a) tujuan diadakannya komunikasi dan (b) karakteristik penerima. Jika komunikasi dimaksudkan untuk memperkenalkan suatu inovasi kepada khalayak yang banyak dan tersebar luas, maka saluran komunikasi yang lebih tepat, cepat dan efisien, adalah media massa. Tetapi jika komunikasi dimaksudkan untuk mengubah sikap atau perilaku penerima secara personal, maka saluran komunikasi yang paling tepat adalah saluran interpersonal. (3) Jangka waktu; proses keputusan inovasi, dari mulai seseorang mengetahui sampai memutuskan untuk menerima atau menolaknya, dan pengukuhan terhadap keputusan itu sangat berkaitan dengan dimensi waktu. Paling tidak dimensi waktu terlihat dalam (a) proses pengambilan keputusan inovasi, (b) keinovatifan seseorang: relatif lebih awal atau lebih lambat dalam menerima inovasi, dan (c) kecepatan pengadopsian inovasi dalam sistem sosial. (4) Sistem sosial; kumpulan unit yang berbeda secara fungsional dan terikat dalam kerjasama untuk memecahkan masalah dalam rangka mencapai tujuan bersama.

Lebih lanjut teori yang dikemukakan Rogers(1995) memiliki relevansi dan argumen yang cukup signifikan dalam proses pengambilan keputusan inovasi. Teori tersebut antara lain menggambarkan tentang variabel yang berpengaruh terhadap tingkat adopsi suatu inovasi serta tahapan dari proses pengambilan keputusan inovasi. Variabel yang berpengaruh terhadap tahapan difusi inovasi tersebut mencakup (1) atribut inovasi (perceived atrribute of innovasion), (2) jeniskeputusan inovasi (type of innovation decisions), (3) saluran komunikasi (communication channels), (4) kondisi sistem sosial (natureof social system), dan (5) peran agen perubah (changeagents).

Sementara itu tahapan dari proses pengambilan keputusan inovasi mencakup: (1) Tahap Munculnya Pengetahuan (Knowledge) ketika seorang individu (atau unit pengambil keputusan lainnya) diarahkan untuk memahami eksistensi dan keuntungan /manfaat dan bagaimana suatu inovasi berfungsi. (2) Tahap Persuasi (Persuasion) ketika seorang individu (atau unit pengambil keputusan lainnya) membentuk sikap baik atau tidak baik. (3) Tahap Keputusan (Decisions) muncul ketika seorang individu atau unit pengambil keputusan lainnya terlibat dalam aktivitas yang mengarah pada pemilihan adopsi ataupenolakansebuahinovasi. (4) Tahapan Implementasi (Implementation), ketika sorang individu atau unit pengambil keputusan lainnya menetapkan penggunaan suatu inovasi. (5) Tahapan Konfirmasi (confirmation), ketika seorang individu atau unit pengambil keputusan lainnya mencari penguatan terhadap keputusan penerimaan atau penolakan inovasi yang sudah dibuat sebelumnya.

Pengelompokan yang bisa dijadikan rujukan adalah pengelompokan berdasarkan kurva adopsi, yang telah duji oleh Rogers (1971). Gambaran tentang pengelompokan adopter sebagai berikut: (1) Innovators: Sekitar 2,5 percent individu yang pertama kali mengadopsi inovasi. Cirinya:petualang, berani mengambil resiko, mobile, cerdas, kemampuan ekonomi tinggi. (2) Early Adopters (Perintis/Pelopor): 13,5 persen yang menjadi para perintis dalam 
penerimaan inovasi. Cirinya: para teladan (pemuka pendapat), orang yang dihormati, akses di dalam tinggi. (3) Early Majority (Pengikut Dini): 34 persen yang menjadi para pengikut awal. Cirinya:penuh pertimbangan, interaksi internal tinggi. (4) Late Majority (Pengikut Akhir): 34 persen yang menjadi pengikut akhir dalam penerimaan inovasi. Cirinya: skeptis, menerima karena pertimbangan ekonomi atau tekanan social, terlalu hati-hati. (5) Laggards (Kelompok Kolot/Tradisional): 16 persen terakhir adalah kaum kolot/tradisional. Cirinya: tradisional, terisolasi, wawasan terbatas, bukan opinion leaders,sumberdaya terbatas.

Hipotesis penelitian: Ada hubungan antara jenis dan ciri inovasi, karakteristik adopter dan Sistem sosial dengan penerimaan inovasi KB; Ada hubungan antara jenis dan ciri inovasi dengan proses jangka waktu penerimaan.

\section{Metode Penelitian}

Penelitian ini dilaksanakan di Pemukiman Komunitas Adat Terpencil Baduy, Desa Kanekes, Kecamatan Leuwidamar, Kabupaten Lebak. Populasi penelitian adalah ibu-ibu akseptor KB di Baduy yang berjumlah 1419 akseptor, terdiri dari 1403 akseptor di Baduy Luar, dan 16 orang lainnya di Baduy Dalam. Mereka tersebar dalam 63 kampung, Penarikan sampel dilakukan dengan cara accidental sampling dengan menetapkan jumlah sampel sebanyak 100 warga, yaitu sampel ditarik berdasarkan kesempatan dan peluang yang ada saat penelitian. Berdasar pertimbangan sifat warga yang cenderung tertutup untuk diajak berbicara, maka penyebaran kuesioner didasarkan pada kesediaan responden untuk mau menjawab kuesioner yang diajukan. Teknik peneyebaran kuesioner dilakukan dengan cara mendatangi akseptor KB dari rumah ke rumah warga serta dengan cara menunggu mereka saat konsul ke rumah Bidan. Waktu penelitian dilaksanakan dari bulan Maret sampai dengan Agustus 2016.

Penelitian, terdiri dari 2 variabel (peubah) Karakteristik Akseptor KB (X) yang terdiri dari 8 karakteristik terpilih (X1-8) (Usia, Jumlah anak, pekerjaan, jarak rumah ke kelinik, jenis $\mathrm{Kb}$ yang dipilih, lama waktu ber-KB, lama memutuskan untuk ber-KB, dan alasan ber-KB), dan peubah tidak bebanya (Y) adalah penerimaan inovasi KB.

Data karakteristik dianalisis dengan menggunakan distribusi frekuensi. Sementara itu, untuk mengetahui hubungan antar peubah dilakukan analisis hubungan dengan koefisien korelasi rank Spearman.

\section{Hasil dan Pembahasan}

Karakteristik yang dimaksud dalam penelitian ini adalah ciri-ciri internal dan eksternal yang melatar belakangi Orang Baduy Luar dan dalam sebagai akseptor KB. Deskripsi karakteristik ini terbatas pada: (1) Usia Akseptor, (2) Jumlah Anak, (3) Pekerjaan, (4) Jarak Rumah Ke Klinik, (5) Asal Kampung, (6) Jenis KB yang dipakai, (7) Lama BerKB, (8) Lama memutuskan untuk Ber-KB, (9) Alat KB yang dinginkan, (10) Sumber informai KB, (11) Alasan Ber-KB, (12) Pernah tidak pernah ganti alat $\mathrm{KB}$, (13) Alasan Ganti alat KB.

\section{Usia Responden}

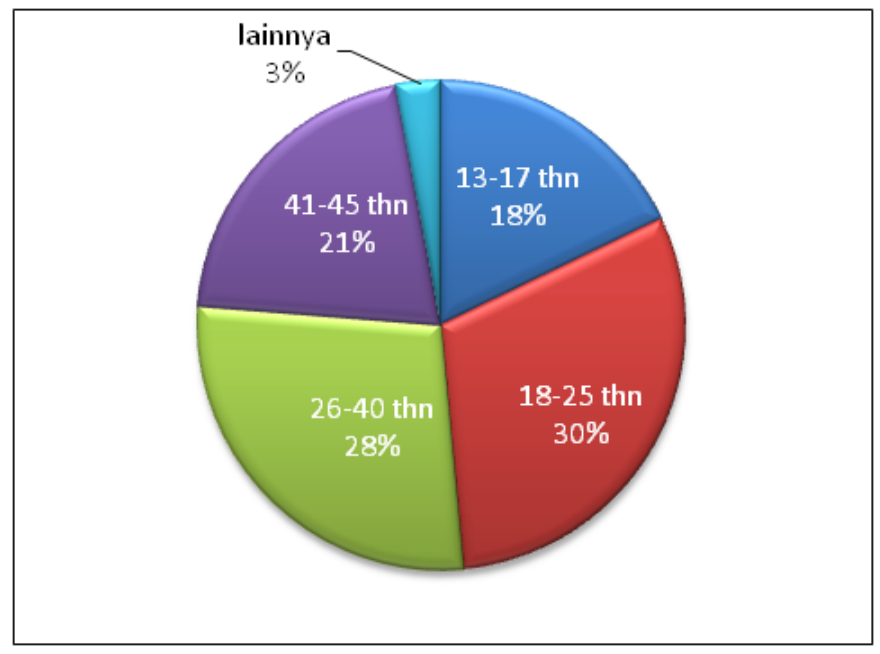

Gambar 1. Sebaran Usia Responden

Usia responden sebenarnya relatif terdistribusi mulai umur 13 sampai 45 tahun, walaupun yang paling banyak adalah antara usia 18-25 tahun, memang usia ini termasuk kelompok pasangan usia subur, sehingga sangat relevan menjadi responden yang dapat memberi informasi lebih akurat.

Jumlah anak yang dimiliki para responden juga sebenarnya relatif merata, yang memiliki 4 anak 29 persen, 2 anak 28 persen, 3 anak 18 persen, 1 anak 21 persen, dan lebih dari 4 anak 4 persen. Walaupun yang paling dominan antara 2 anak dan 4 anak. Hanya belum terlihat dalam data ini pada usia berapa 
dari responden yang memiliki anak sampai 4 orang. Walaupun demikian secara keseluruhan responden dengan jumlah anak paling banyak 4 orang berarti sebenarnya masyarakat disana tidak termasuk dalam golongan "keluarga besar".

Jenis Pekerjaan responden sebagian besar atau 63 persen adalah penenun kain, 11 persen diantaranya bekerja jualan/pedagang, dan selebihnya yakni sejumlah 26 persen responden bekerja selain sebagai penenun dan pedagang, seperti petani atau hanya sebagai ibu rumah tangga.

Berdasarkan data di atas ada kecenderungan para kaum wanita (istri) di masyarakat tersebut dalam mencari pendapatan tambahan dengan melakukan kegiatan menenun, hal ini sangat boleh jadi menenun merupakan keahlian utama yang dimiliki masyarat itu secara turun temurun. Kegiatan lain relatif jumlahnya cukup besar hanya disini kegiatannya cukup beragam. Jumlah yang berjualan relatif sedikit, hal ini sangat boleh jadi karena keterbataan permodalan.

\section{Jarak Rumah ke Klinik Bidan}

Jarak rumah tempat tinggal responden ke klinik kesehatan (klinik bidan atau puskesmas), maka diperoleh data sebagai berikut; lebih dari 55 orang responden rumahnya berjarak 2 jam perjalanan ke klinik bidan, 22 orang rumahnya berjarak 3 jam perjalanan ke klinik bidan, 10 orang memiliki jarak rumah ke klinik bidan 1 jam perjalanan, 5 orang rumahnya berjarak 1-2 kilometer ke klinik bidan dan sisanya 8 yang lain kurang dari 1 kilometer (Gambar 2). Berdasarkan data ini, rata-rata responden bertempat tinggal cukup jauh dari klinik bidan terdekat di wilayah mereka untuk mendapatkan layanan KB.

Bila dilihat dari diagram chart di atas sebenarnya mereka memiliki sikap antusias untuk ber $\mathrm{KB}$, sebab mayoritas responden, mereka harus menempuh perjalanan yg cukup lama (2 jam) sampai bisa ke lembaga kesehatan (bidan), dan itu mereka bersedia melakukannya. Bahkan ada yang harus menempuh perjalanan sampai 3 jam untuk mendapatkan layanan $\mathrm{KB}$ dan semua itu biasanya mereka lakukan dengan berjalan kaki. Fenomena ini perlu mendapat mendapat perhatian dari pihak dinas kesehatan setempat, terkait dengan semangat mereka dalam ber $\mathrm{KB}$, sehingga penerapan program ini di masyarakat tersebut berpeluang lebih berhasil.

Jenis alat KB (kontrasepsi) yang digunakan oleh para responden selama ini, maka diperoleh data bahwa mayoritas perempuan Baduy Luar (mencapai 82 persen) yang menjadi akseptor KB menggunakan metode suntik sebagai pilihan alat KB yang dipakai, sementara 15 persen lainnya menggunakan pil KB, dan sisanya ( 3 persen) menggunakan implant sebagai pilihan alat KB yang dipakai.

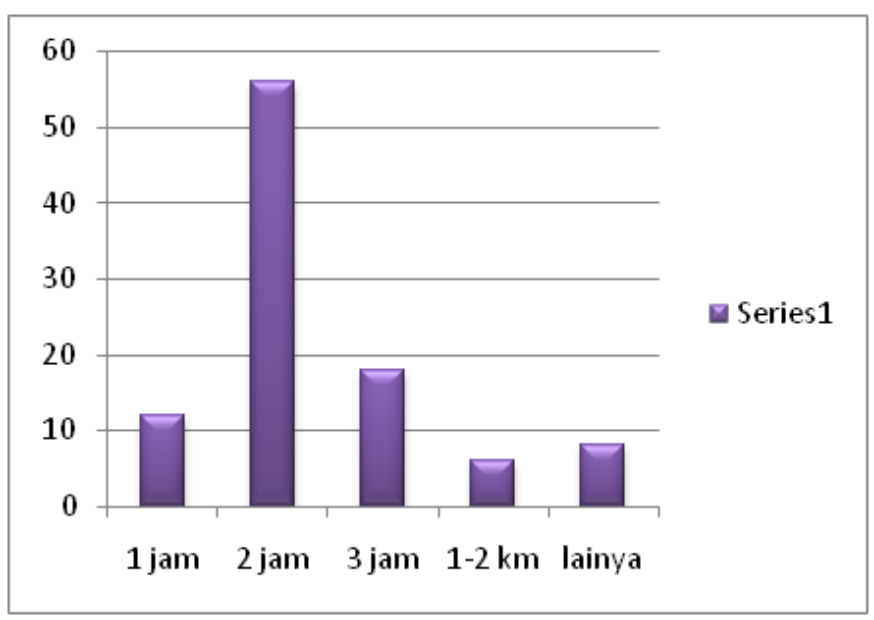

Gambar 2. Sebaran Responden Menurut Jarak Rumah ke Klinik

Memperhatikan data di atas sangat jelas bahwa kaum wanita dalam masyarakat tersebut lebih meyakini menggunakan alat kontrasepsi "suntik", sangat boleh jadi alat kontrasepsi ini relatif lebih praktis dan waktunya agak lama (sebulan sekali), dan tidak menutup kemungkinan alat kontrasepsi pada masyarakat ini, dianggap tidak banyak ditemukan afek negatifnya. Walaupun demikian ada juga yang menggunakan alat kontra sepsi lain (pil) walaupun jumlahnya hanya 25 persen nya dari yang menggunakan kontrasepsi suntik, hal ini perlu mendapat kajian, mengapa mengapa alat kontra sepsi ini masih sedikit penggunaannya, apakah masih kurang sosialisasi atau bagaimana, begitu juga dengan alat kontrasepsi lain, mengapa belum banyak mereka meminati.

Terkait dengan berapa lama responden telah mengikuti program KB atau mengggunakan alat kontrasepsi, maka diperoleh data sebagai berikut; 42 persen di antaranya mengaku sudah 1-3 tahun ber-KB, mereka yang sudah ber-KB selama 4-6 tahun ada 18 persen, sementara 4 persen mengaku telah menggunakan alat KB 7-9 tahun dan yang lebih dari 10 tahun ber-KB ternyata cukup besar, sekitar 36 persen responden. 
Terkait dengan lama ber KB, sebenarnya mereka ada yang sudah lama ber KB yaitu hampir 30 persen lebih responden menyatakan telah ber $\mathrm{KB}$ antara 10 - 12 tahun, fenomena ini sebenarnya cukup menarik untuk ditelah para petugas dinas kesehatan dan khusunya petugas PLKB. Walaupun yang mayoritas dari responden baru ber $\mathrm{KB}$ antara 1-3 tahun, yang terakhir ini perlu terus diberi motivasi dan difasilitasi oleh petugas dan dinas terkait, sehingga secara bertahap mereka menjadi akseptor KB lestari, begitu juga bagi responden yang sudah menjalaninya sekitar 4- 6 tahun berjalan, perlu terus dijaga, difasilitasi dan dibuat nyaman layanannya.

\section{Lama Memutuskan untuk ber-KB}

Dibutuhkan waktu tertentu bagi seorang responden ketika dia akan memutuskan untuk menjadi akseptor KB. Masing-masing responden membutuhkan waktu yang berbeda-beda saat memutuskan akan ikut program KB (Gambar 3).

Berdasarkan olah data yang dilakukan, 23 persen resonden membutuhkan waktu antara 1-3 bulan untuk memutuskan ikut KB, 42 persen responden lain membutuhkan waktu lebih lama, yakni 6 bulan untuk pada akhirnya mengambil keputusan ikut program $\mathrm{KB}, 30$ persen responden bahkan membutuhkan waktu hingga satu tahun untuk memutuskan ikut KB, dan sekitar 5 persen responden lainnya memutuskan ber-KB dalam waktu kurang dari 1 tahun.

Mayoritas responden menyatakan bahwa mereka dalam memutuskan untuk ber $\mathrm{KB}$ hanya kisaran 6 bulan, kalau kita cermati untuk setingkat

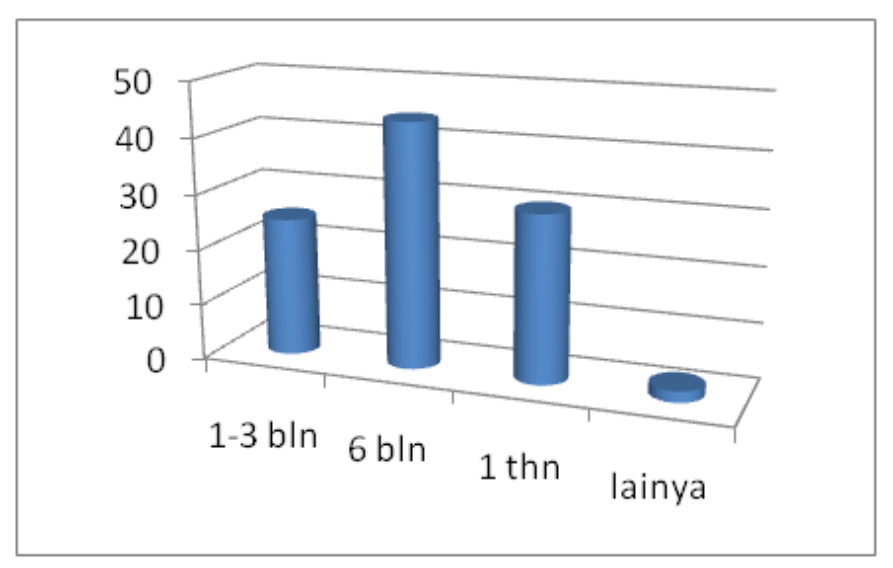

Gambar 3. Sebaran Responden Menurut Lama Memutuskan untuk Ber-KB masyarakat disana yang relatif kurang banyak informasi yg masuk, sementara disisi lain pengaruh adat yang kuat, maka kisaran waktu memutuskan ber KB, termasuk yang singkat, bahkan ada yang memutuskan ber KB hanya 1-3 bulan saja. Responden yang harus memutuskan sampai 1 tahun, itu perlu mendapat perhatian yang ekstra dari para petugas lapangan. Hasil penelitian Dimyati (2016), menjelaskan bahwa peran petugas lapangan, baik kader maupun petugas kesehatan di Baduy sangat berpengaruh besar bagi penerimaan layanan kesehatan oleh warga Baduy yang dikenal kukuh dalam memegang hukum adat.

\section{Alat KB Awal yang Diinginkan}

Saat ditanyakan tentang jenis alat $\mathrm{KB}$ apa yang diinginkan digunakan oleh responden pada waktu awal mereka akan memutuskan ber-KB, jawaban dari responden sebagian besar pada walnya menginginkan KB dengan cara suntik (77 orang), 15 orang lainnya menghendaki menggunakan pil pada awal ber-KB, 3 orang responden menghendaki memakai alat KB implant, dan 1 orang lainnya pada waktu awal ber-KB menginginkan memakai alat KB spiral/IUD (Gambar 4).

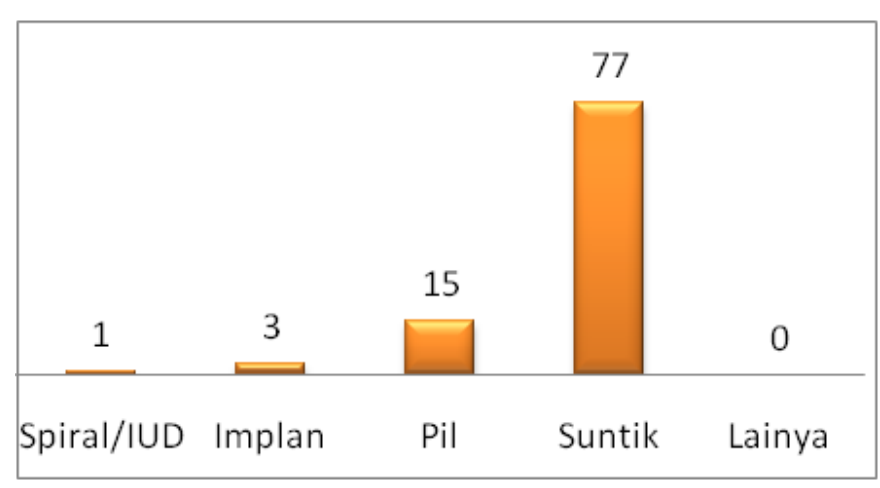

Gambar 4. Sebaran Responden Menurut Jenis Alat KB yang Diingnkan

Berdasarkan data ini, dapat disimpulkan bahwa mayoritas ibu-ibu warga KAT Baduy yang memutuskan untuk ber-KB ternyata menginginkan menggunakan $\mathrm{KB}$ dengan metode suntik. Artinya KB suntik menjadi pilihan yang paling popular atau paling banyak diinginkan untuk digunakan oleh responden.

Seperti halnya data sebelumnya bahwa 
kecenderungan alat kontrasepsi yang kemungkinan akan dipilih oleh responden (Pasangan Usia Subur) ketika mereka jadi untuk ber KB adalah kontra sepsi "suntik", walaupun ada yang memilih alat kontra sepsi pil dan inplan tp ini jumlahnya relatif kecil. Gejala ini perlu dipelajari oleh para petugas, sebagai antisipasi kemungkinan adanya permasalahan dikemudian hari, selain itu perlu dipikirkan dan diupayakan para petugas sehingga dapat dilakukan diversifikasi alat kontrasepsi kepada mereka, sepanjang alat kontrasepsi itu dapat dipertanggungjawabkan keamanan dan kenyamanannya bagi mereka dan terjaga ketersediaannya.

Sumber informasi yang menjadi rujukan para responden untuk mendapatkan informasi seputar Keluarga Berencana (KB). Sebagian besar responden mendapatkan informasi tentang $\mathrm{KB}$ dari saudara atau tetangga mereka, hanya 22 persen responden yang mengakui jika petugas kesehatan atau bidan merupakan sumber informasi KB mereka, kader posyandu menjadi sumber informasi $\mathrm{KB}$ bagi 21 persen responden, dan perangkat desa/ketua adat, atau kakolot adat hanya disebutkan oleh 7 persen responden sebagai sumber informasi KB. Sisanya, sejumlah 1 persen mendapatkan informasi $\mathrm{KB}$ dari sumber lain seperti teman atau media. Eksistensi kader posyandu yang menjadi salah satu sumber utama informasi mengenai $\mathrm{KB}$ di Baduy ini sejalan dengan temuan penelitian mengenai kinerja kader posyandu oleh Simanjuntak (2014) yang disimpulkan cukup baik, dalam arti mereka menjalankan tugas dan tanggung jawabnya dengan baik. Hasil studi Simanjuntak juga mengungkap, semakin tinggi insentif yang diterima kader dan pernah tidaknya kader mengikuti pelatihan memberikan pengaruh terhadap peningkatan kinerja kader posyandu. Meski demikian, dalam studi Mastuti (2003) tak ada hubungan keinginan terhadap insentif dengan kelangsungan kader posyandu. Hal ini juga ditemukan dalam penelitian Dimyati (2016) soal motivasi menjadi kader Posyandu di Baduy yang lebih banyak dilatari oleh keinginan untuk berkontribusi bagi pembangunan kesehatan warga Baduy.

Berdasarkan data sumber informasi $\mathrm{KB}$ ibu-ibu warga KAT Baduy ini, setidaknya kita bisa mendapatkan gambaran bahwa saudara dan tetangga merupakan sumber informasi utama $\mathrm{KB}$ ternyata. Justru tenaga kesehatan/bidan yang dianggap leading sektor program KB hanya disebutkan oleh 22 persen responden sebagai sumber informasi KB. Meski tampak lebih rendah, peran petugas kesehatan ini masih tetap signifikan karena 21 persen responden mengaku kalau mereka mendapatkan informasi KB dari kader posyandu yang nota bene merupakan para kader yang dibangun dan dibina oleh tenaga kesehatan di sana. Penelitian oleh Dimyati (2016) bahkan menemukan signifkansi peran beberapa orang tenaga kesehatan di Baduy dalam mendobrak tata nilai dan pikukuh karuhun yang kerap menjadi hambatan bagi pelayanan kesehatan medis modern bagi warga Baduy, termasuk dalam pelayanan KB.

Apa yang sesungguhnya menjadi alasan perempuanKAT Baduy ber-KB? jawaban yang paling banyak disebut sebagai alasan ikut program $\mathrm{KB}$ adalah demi menjarangkan anak (36 persen), saran bidan atau tenaga kesehatan ternyata cukup mempengaruhi perempuan Baduy untuk ikut program $\mathrm{KB}$, yakni sampai angka 33 persen responden ber-KB karena mengikuti saran bidan, 16 persen responden lain mengatakan membatasi jumlah anak sebagai alasan mereka ikut $\mathrm{KB}$, dan 11 persen responden mengakui kalau mereka ber-KB demi alasan mengurangi beban ekonomi yang harus ditanggung, dan sisanya (4 persen) menyebut alasan yang lain sebagai dasar mereka ber-KB (Gambar 5).

\section{Alasan Ber-KB}

Data di atas ternyata informasi KB yang banyak diterima oleh masyarakat disana adalah dari saudara/tetangganya, sementara dari dari petugas kesehatan dan lembaga layanan kesehatan relatif lebih sedikit, hal itu sebenarnya perlu mendapat introspeksi diri dari para petugas dan lembaga kesehatan setempat, untuk lebih proaktif dan berusaha lebih dekat dengan kaum wanita dan keluarga masyarakat tersebut, sebab info KB yang diperoleh bukan dari pertugas dan atau layanan kesehatan, kecuali dari ibu bidan Eros Rosita yang bisa dikatakan amat diterima dan dipercaya oleh masyarakat Baduy.

Sementara peran perangkat desa maupun tokoh-tokoh setempat malah masih sangat minim sekali untuk menjadi sumber informasi maupun pendorong bagi pasangan usia subur (PUS) untuk memahami serta meyakini perlunya ber KB.

Secara umum, perempuan KAT Baduy yang menjadi akseptor KB mengakui konsisten menggunakan alat $\mathrm{KB}$ tertentu dalam jangka waktu 
yang panjang sejak mereka pertama ber-KB. Artinya mereka tidak pernah ganti alat KB sejak pertama kali mereka ikut KB. Jumlah mereka yang tidak pernah berhanti alat $\mathrm{KB}$ ini mencapai 80 persen sementara yang 20 persen lainnya mengakui pernah berganti alat KB dengan beberapa alasan.

Dalam perjalanan ikut ber $\mathrm{KB}$, pada umumnya mereka jarang berganti alat kontrasepsi, hal ini sebenarnya mereka cukup konsisten dan ada kecenderungan merasa nyaman dengan alat kontra sepsi tertentu, namun demikian para petugas perlu terus mencermati dan memantau dalam perjalanan selanjutnya untuk mengantisipasi bila ada perubahan perkembangan terkait alat kontra sepsi tersebut (misal terjadi kelangkaan stok kontra sepsi tersebut), sebab hal itu dapat menimbulkan permasalahan yg sebelumnya tidak diprediksikan. Selain itu dengan adanya akseptor yang berganti alat kontra sepsi juga perlu mendapat perhatian dan menelusuri kenapa mereka berganti, apakah ada permasalahan, efak samping atau alasan lain yang perlu dicari solusinya sehingga mereka tetap nyaman dan tidak menurunkan kepercayaan mereka terhadap alat kontra sepsi yang mereka gunakan.

Sebagian perempuan Baduy yang ber-KB mengaku pernah berganti alat KB. Sebagian besar memilih berganti alat KB karena mencari alternatif alat KB yang jauh lebih praktis digunakan (33 persen), berganti alat KB karena mengikuti saran bidan (28 persen), karena ketidak cocokan yang menimbulkan efek samping bagi tubuh ( 22 persen), dan 11 persen responden lain mengaku berganti alat $\mathrm{KB}$ karena alat KB yang sebelumnya (lama) lebih susah didapatkan. Sementara, sisanya yang lain (6 persen) berganti alat $\mathrm{KB}$ dengan beragam alasan diluar alasan yang tadi disebutkan.

Responden sama seperti hal nya akseptor KB lainnya, yang cenderung lebih menghendaki alat kontrasepsi yang praktis dalam penggunaannya, hal ini harus menjadi bahan pemikiran terkait dengan pembuatan alat kontrasepsi, sebaiknya yang memang benar-benar mudah digunakan, simpel, nyaman dan tentunya terbebas dari efek samping. Walaupun demikian tercatat dalam data yang menunjukkan bahwa mereka bergantu alat kontra sepsi karena memang tidak cocok dengan mondisi fisik dan metabolismenya, termasuk karena masih ditemukan adanya efek samping yang tidak diharapkan. Tapi hal yang menarik mereka juga berganti alat kontrasepsi karana atas saran bidang itu sendiri, hal ini perlu ditelusuri apakah memang bidan memberi pertimbangan karena alasan kesehatan atau karena keterbatasan stok alat kontra sepsi tersebut sehingga disarankan untuk ganti alat kontra sepsi, bila hal terakhir ini yang terjadi maka seharusnya bisa dicari jalan keluarnya (misal diperbanyak stok), sebab yang perlu diantisipasi jangan sampai menimbulkan masalah di kemudian hari. Selanjutnya digambarkan hasil analisis hubungan antar variable sesuai dengan hipotesis penelitian dan tujuan penelitian ini.

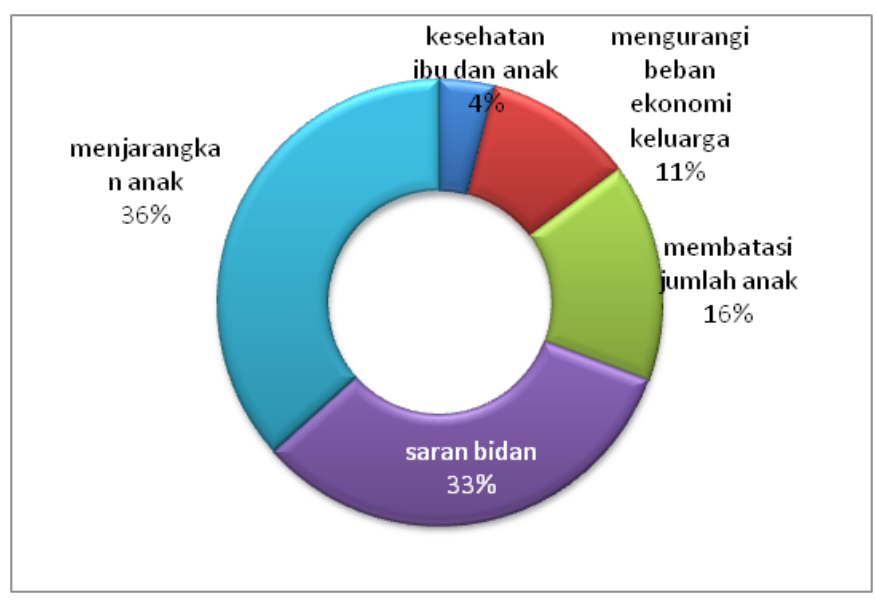

Gambar 5. Sebaran Responden Menurut Alasan Melakukan KB

\section{Asal Kampung Responden}

Lokasi tempat tinggal para responden berdasarkan lokasi kampung mereka cukup tersebar secara variatif, mulai dari kampung yang paling jauh jaraknya ke klinik bidan hingga yang paling dekat terwakili oleh responden dalam penelitian ini.

Hasil analisis antar variabel penelitian, meliputi: 1). Hubungan antara karakteristik komunikan (X1) dengan efektifitas penerimaan inovasi (Y), 2). Hubungan antara sistem sosial (X2) dengan efektifitas penerimaan inovasi (Y), 3). Hubungan antara jenis saluran komunikasi (X3) dengan efektifitas penerimaan inovasi (Y), 4). Jenis dan ciri inovasi (X4) yang ada apakah dapat mendorong terjadinya efektifitas penerimaan inovasi (Y), 5). Berikut ini adalah penjelasan hubungan antar variabel sebagaimana disebutkan di atas: 


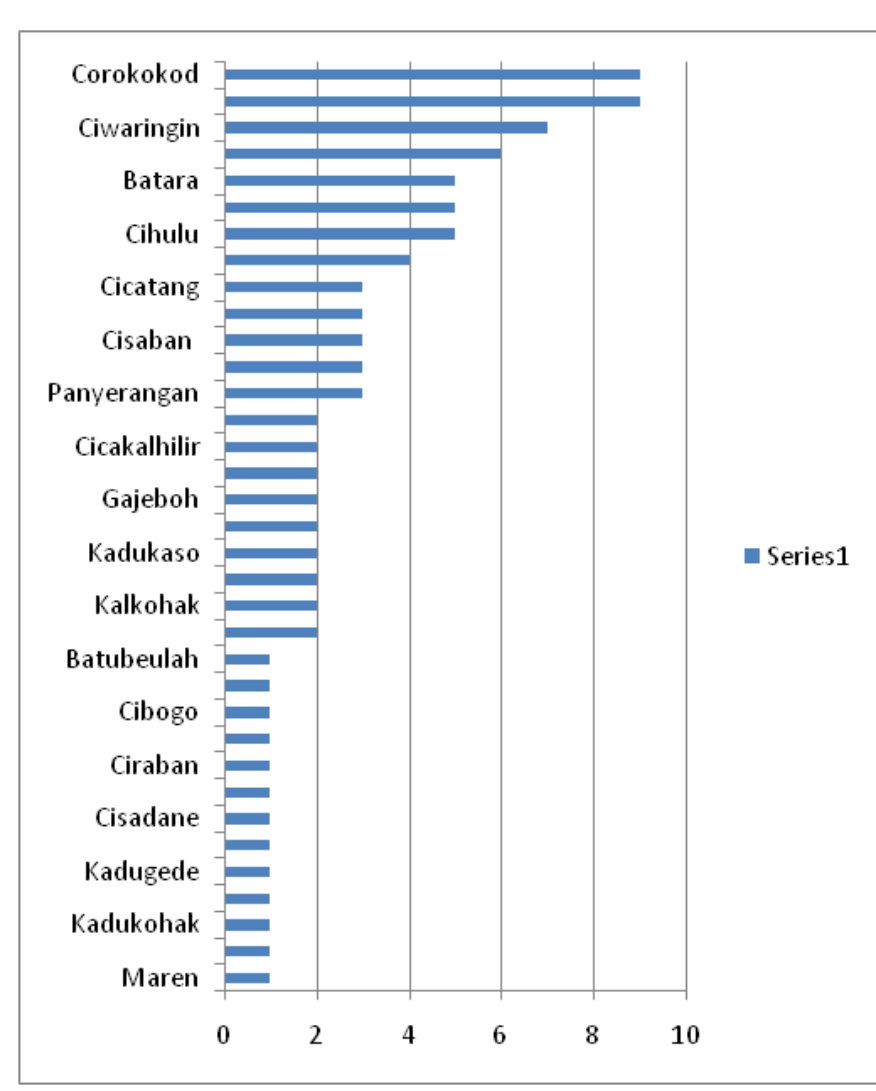

Gambar 6. Sebaran Responden Menurut Asal Kampung

\section{Hubungan antara Karakteristik Sosial Akseptor dan Efektifias Penerimaan Inovasi}

Berdasarkan hasil perhitungan SPSS korelasi product moment, koefisien determinant versi 17 (lihat lampiran) diperoleh data untuk karakteristik dengan efektifitas penerimaan inovasi sebagi berikut: Koefisien korelasi $(\mathrm{r})=0,368$, artinya terjadi korelasi yang positif, bahwa hubungan antara karakteristik komunikan dengan efektifitas penerimaan inovasi mempunyai hubungan yang "lemah" (lihat pedoman intepretasi koefisien korelasi). Koefisien determinan $\left(\mathrm{r}^{2}\right)=0,135$, berarti pengaruh karakteristik komunikan terhadap efektifitas penerimaan inovasi hanya sebesar 13,5 persen, sedangkan sisanya dipengaruhi oleh faktor lain. Walaupun pengaruhnya kecil tetapi berpeluang terjadinya penerimaan inovasi.

T hitung $=3,934>\mathrm{t}$ tabel $=1,980$, artinya $\mathrm{H}_{\mathrm{o}}$ ditolak dan $\mathrm{H}_{\mathrm{a}}$ diterima, hal ini menunjukkan bahwa terdapat hubungan yang signifikan antara karakteristik komunikan dengan efektifitas penerimaan inovasi (dapat diberlakukan untuk populasi penelitian). Persamaan regresi diperoleh : $\mathrm{Y}=13,098+0,767 \mathrm{X}_{1}$, artinya bahwa bila terjadi perubahan karakteristik komunikan maka akan mendorong terjadinya penerimaan inovasi.

Dari perhitungan di atas terdapat korelasi yang positif antara karakteristik komunikan (adopter/ akseptor KB) dengan efektifitas penerimaan inovasi. Meskipun hubungan itu terbilang lemah, yakni dengan koefisien korealasi 0,368 . Korelasi positif antara karakteristik adopter $\mathrm{KB}$ dengan efektivitas $\mathrm{KB}$ ini dapat diperkuat oleh temuan penelitian Dimyati (2016) yang mengungkap, penerima layanan kesehatan medis modern di Baduy pada masa awal layanan kesehatan masuk adalah mereka yang memiliki keterbukaan karena intertaksinya dengan masyarakat luar yang lebih intensif, seperti mantan jaro dan keluarganya yang memiliki keterbukaan lebih luas dibandingkan warga Baduy umumnya karena interaksi mereka dengan dunia luar yang lebih intensif.

Hal ini bisa jadi karena bila melihat usia akseptor KB di KAT Baduy sebagian besar berusia diantara 18-25 tahun. Sementara dari jumlah anak, sebagian besar mereka yang memiliki anak diatas 3 orang anak. Terlebih bila dilihat dari jarak rumah para akseptor $\mathrm{KB}$ ke klinik bidan terdekat, lebih dari 50 persen akseptor membutuhkan waktu 2 jam perjalanan. Cukup membutuhkan waktu yang tidak sedikit untuk mencapai klinik bidan yang melayani KB.

Hal ini dapat dijelaskan melalui data deskripsi terkait jangka waktu atau sudah berapa lama mereka ikut KB data menunjukkan terkait dengan lama ber $\mathrm{KB}$, sebenarnya mereka ada yang sudah lama ber KB yaitu hampir 30 persen lebih responden menyatakan telah ber $\mathrm{KB}$ antara $10-12$ tahun, fenomena ini sebenarnya cukup menarik untuk ditelah para petugas dinas kesehatan dan khusunya petugas PLKB.

Walaupun yang mayoritas dari responden baru ber $\mathrm{KB}$ antara 1-3 tahun, yang terakhir ini perlu terus diberi motivasi dan difasilitasi oleh petugas dan dinas terkait, sehinhgga secara bertahap mereka menjadi akseptor KB lestari, begitu juga bagi responden yang sudah menjalaninya sekitar 46 tahun berjalan, perlu terus dijaga, difasilitasi dan dibuat nyaman layanannya.

Jika dilihat berdasarkan jarak rumah tempat tinggal responden ke klinik kesehatan (klinik bidan atau puskesmas), maka diperoleh data sebagai berikut; lebih dari 55 orang responden rumahnya berjarak 2 jam perjalanan ke klinik bidan, 22 orang 
rumahnya berjarak 3 jam perjalanan ke klinik bidan, 10 orang memiliki jarak rumah ke klinik bidan 1 jam perjalanan, 5 orang rumahnya berjarak 1-2 kilometer ke klinik bidan dan sisanya 8 yang lain kurang dari 1 kilometer. Artinya, kita bisa katakan berdasarkan data ini, rata-rata responden bertempat tinggal cukup jauh dari klinik bidan terdekat di wilayah mereka untuk mendapatkan layanan KB. Artinya meskipun pengaruh karakteristik pada efektivitas hanya 13,54 persen kenyataannya antusias warga Baduy untuk ber KB sangat baik, mereka rela menumpuh perjalanan lebih dari 2 jam dengan berjalan kaki.

\section{Hubungan antara Sistem Sosial dengan Efektifitas Penerimaan Inovasi}

Berdasarkan data hasil perhitungan statistik terlihat, koefisien korelasi $(\mathrm{r})=-0,095$, artinya terjadi korelasi yang negatif, bahwa sistem sosial yang ada dapat menjadikan tidak efektifnya penerimaan inovasi dan hubungan tersebut "sangat lemah". Koefisien determinan $\left(\mathrm{r}^{2}\right)=0,009$, berarti pengaruhnya sangat kecil yaitu 0,9 persen, hal ini menunjukkan pengaruhnya sangat lemah (bisa dikatakan tidak ada pengaruh).

$\mathrm{T}$ hitung $=-0,951<\mathrm{t}$ tabel $=1,980$ artinya $\mathrm{H}_{\mathrm{o}}$ diterima dan $\mathrm{H}_{\mathrm{a}}$ ditolak, hal ini menunjukkan bahwa tidak terdapat hubungan yang signifikan antara sistem sosial dengan efektifitas penerimaan inovasi (tidak dapat diberlakukan untuk populasi penelitian). Persamaan regresi diperoleh: $\mathrm{Y}=40,522$ $-0,195 \mathrm{X}_{2}$, artinya bahwa sistem sosial yang ada dapat mengurangi efektifitas penerimaan inovasi, karena nilai koefisien regresinya negatif.

Kondisi ini bisa menjelaskan mengapa korelasi antara sistem sosial dengan efektifitas penerimaan inovasi bernilai negatif atau hampir tanpa pengaruh, bila diperhatikan tren untuk menjadi akseptor KB bagi perempuan di KAT Baduy sejak tahun 2006 sampai tahun 2016 ini sangat besar. KB tidak lagi menjadi suatu hal yang terlarang di mata ibu-ibu KAT Baduy karena kini tak lagi dianggap sebagai larangan adat.

Pengambilan keputusan ber KB Mayoritas responden menyatakan bahwa mereka dalam memutuskan untuk ber KB hanya kisaran 6 bulan, kalau kita cermati untuk setingkat masyarakat disana yang relatif kurang banyak informasi yg masuk, sementara disisi lain pengaruh adat yang kuat, maka kisaran waktu memutuskan ber $\mathrm{KB}$, termasuk yang singkat, bahkan ada yang memutuskan ber KB hanya 1-3 bulan saja. Akseptor yang harus memutuskan sampai 1 tahun, itu perlu mendapat perhatian yang ekstra dari para petugas lapangan. Selain itu ada factor lembaga adat sudah memberikan izin KB digunakan untuk KAT Baduy, bahkan di Baduy Dalam tercatat ada 16 akseptor KB di Kampung Cibeo.

\section{Hubungan antara Jenis Saluran Komunikasi dengan Efektifitas Penerimaan Inovasi (KB)}

Perhitungan statistika memperlihatkan bahwa koefisien korelasi (r) $=0,408$, artinya terdapat korelasi yang positif, bahwa hubungan antara jenis saluran komunikasi dengan efektifitas penerimaan inovasi mempunyai hubungan yang "cukup kuat".

Koefisien determinan $\left(\mathrm{r}^{2}\right)=0,167$, berarti pengaruh jenis saluran komunikasi terhadap efektifitas penerimaan inovasi sebesar 16,7 persen, sedangkan sisanya dipengaruhi oleh faktor lain. Hal ini menunjukkan bahwa cukup berpeluang terjadinya penerimaan inovasi, apabila jenis saluran komunikasi diperbarui atau dipilih dengan yang paling tepat sesuai situasi di lingkungan sosial setempat.

T hitung $=4,450>\mathrm{t}$ tabel $=1,980$, artinya $\mathrm{H}_{\mathrm{o}}$ ditolah dan $\mathrm{H}_{\mathrm{a}}$ diterima, hal ini menunjukkan bahwa terdapat hubungan yang signifikan antara jenis saluran komunikasi dengan efektifitas penerimaan inovasi (dapat diberlakukan untuk populasi penelitian).

Persamaan regresi diperoleh: $\mathrm{Y}=9,462+$ $1,054 \mathrm{X}_{3}$, dengan koefisien regresi yang positif berarti bila terjadi perubahan pada jenis saluran komunikasi atau dipilih jenis saluran komunikasi yang tepat maka cukup berpeluang untuk mendorong terjadinya penerimaan inovasi oleh masyarakat setempat.

Kondisi ini bisa menjelaskan bahwa sangat bisa dipahami jika terdapat hubungan yang kuat antara jenis saluran komunikasi dengan efektifitas penerimaan inovasi disebabkan akseptor KB yang merupakan ibu-ibu dari KAT Baduy memiliki relasi sosial yang dengan tetangga dan saudara yang menjadi sumber informasi KB. Peran bidan atau tenaga kesehatan sebagai tokoh tenaga kesehatan yang membuka layanan KB di KAT Baduy cukup besar, termasuk pengaruh saluran dari kader Posyandu yang dibentuk dan bina oleh para bidan ternyata cukup berpengaruh signifikan. Besarnya peran tenaga kesehatan dan kader posyandu sebagai saluran 
infrmasi KB di Baduy tentu berbeda dibandingkan di tempat lain. Justru menurut temuan penelitian Devi, dkk (2016) kapasitas kader dalam penyluhan KB di Kota Palembang terbilang rendah. Pengembangan kapasitas kader KB ini memang dipengaruhi oleh beberapa faktor, yakni pengalaman, pelatihan yang diikuti, dukungan penyuluh $\mathrm{KB}$, dan dukungan informasi.

\section{Hubungan antara Jenis dan Ciri Inovasi (KB) dengan Efektifitas Penerimaan Inovasi}

Setelah dianalisi menggunakan SPSS versi 17, didapatkan koefisien korelasi (r) $=0,127$, artinya terdapat korelasi yang positif, bahwa jenis dan ciri inovasi yang ada dapat mendorong terjadinya efektifnya penerimaan inovasi, walaupun hubungannya "sangat lemah". Koefisien determinan $\left(r^{2}\right)=0,016$, berarti pengaruh jenis dan ciri inovasi terhadap efektifitas penerimaan inovasi sangat kecil yaitu 1,6 persen, hal ini menunjukkan pengaruhnya sangat lemah. $\mathrm{T}$ hitung $=-1,274<\mathrm{t}$ tabel $=1,980$ artinya $\mathrm{H}_{\mathrm{o}}$ diterimadan $\mathrm{H}_{\mathrm{a}}$ ditolak, hal ini menunjukkan bahwa tidak terdapat hubungan yang signifikan antara jenis dan ciri inovasi dengan efektifitas penerimaan inovasi (tidak dapat diberlakukan untuk populasi penelitian)

Persamaan regresi diperoleh: $\mathrm{Y}=39,923$ - $0,161 \mathrm{X}_{4}$, persamaan ini menunjukkan bahwa koefisien regresi negatif, artinya bahwa jenis dan ciri inovasi yang terjadi di masyarakat tersebut dapat memperlemah terjadinya penerimaan inovasi.

Kondisi ini bisa dijelaskan, rata-rata akseptor KB di Baduy lebih memilih jenis alat $\mathrm{KB}$ menggunakan suntik yang dinilai jauh lebih praktis dibandingkan dengan jenis alat $\mathrm{KB}$ yang lain. Hal demikian menjadikan jenis inovasi (alat KB) dimata akseptor/adopter tidak dianggap sebagai sebuah inovasi yang membutuhkan pemikiran/perhatian/ pertimbangan besar di mata akseptor.

Selain suntik, jenis alat KB lain yang digunakan oleh sebagian kecil akseptor $\mathrm{KB}$ di Baduy adalah menggunakan pil. Pil sangat mungkin kurang mendapat tempat dibandingkan dengan alat KB suntik karena kerepotan penggunaanya, yang membutuhkan disiplin waktu secara konsisten untuk mengkonsumsinya. Ketersediaan pil KB saat stok habis juga kadang cukup menghadapi kendala untuk mendapatkannya. Hal ini bisa saja terjadi jenis KB yang mereka pilih dengan keberterimaan pada inovasi KB lebih disebabkan oleh banyaknya warga yang sudah menerima cara hidup dengan $\mathrm{KB}$, baik untuk kesehatan anak dan ibu maupun untuk kesejahteraan keluarga hal ini terlihat dari trend peserta $\mathrm{KB}$ di KAT Baduy selalui bertambah, sebagai data dalam latar belakang masalah, hal ini juga dikuatkan oleh data deskripsi mengenai keputusannya menerima $\mathrm{KB}$, data menunjukkan Berdasarkan olah data yang dilakukan, 23 persen responden membutuhkan waktu antara 1-3 bulan untuk memutuskan ikut $\mathrm{KB}, 42$ persen responden lain membutuhkan waktu lebih lama, yakni 6 bulan untuk pada akhirnya mengambil keputusan ikut program KB, 30 persen responden bahkan membutuhkan waktu hingga satu tahun untuk memutuskan ikut KB, dan sekitar 5 persen responden lainnya memutuskan ber-KB dalam waktu kurang dari 1 tahun.

Mayoritas responden menyatakan bahwa mereka dalam memutuskan untuk ber $\mathrm{KB}$ hanya kisaran 6 bulan, kalau kita cermati untuk setingkat masyarakat disana yang relatif kurang banyak informasi yang masuk, sementara disisi lain pengaruh adat yang kuat, maka kisaran waktu memutuskan ber KB, termasuk yang singkat, bahkan ada yang memutuskan ber KB hanya 1-3 bulan saja. Akseptor yang harus memutuskan sampai 1 tahun, itu perlu mendapat perhatian yang ekstra dari para petugas lapangan. Artinya apapun jenis inovasi KB mereka sudah mau menerima, yang penting cocok sesuai dengan kebutuhannya.

Kenyataan memang demikian bila memperhatian masyarakat Baduy Luar di Kampung Kadu Ketug yang berbatasan langsung dengan masyarakat Desa di luar tanah ulayat kita dapat menyaksikan banyak pergeseran, perubahan pada gaya hidup penduduk di Kaduketug, kita tidak sulit menemukan Masyarakat Baduy yang memiliki HP, Smartphone, dan beberapa gaya hidup modern seperti cara berpakaian dan bicara.

Kondisi ini bisa dijelaskan melalui korelasi antara sistem sosial dengan efektifitas penerimaan inovasi bernilai negatif atau hampir tanpa pengaruh, bila diperhatikan tren untuk menjadi akseptor $\mathrm{KB}$ bagi perempuan di KAT Baduy sejak tahun 2006 sampai tahun 2016 sangat massif. KB tidak lagi menjadi suatu hal yang terlarang bagi ibu-ibu KAT Baduy karena kini tak lagi dianggap sebagai larangan adat. Hal ini bisa dikatakan bahwa sudah banyak 
juga terjadi pergeseran nilai di KAT Baduy, dengan harapan tentunya pergeseran ini kearah lebih baik dalam kesejahteraan, KB bisa menjadi salah satu pintu masuk untuk peningkatan kesejahteraan.

\section{Kesimpulan}

Penyebaran KB sebagai satu inovasi di Komunitas Adat Terpencil (KAT) Baduy, di Desa Kanekes, Kecamatan Leuwidamar, Kabupaten Lebak cukup diterima dan berhasil dengan baik. Hal ini ditandai dengan jumlah akseptor KB di KAT Baduy yang terus bertambah dan tersebar dari tahun ke tahun secara lebih merata. Bahkan, di kampung Baduy Dalam pun kini sudah ada puluhan ibu-ibu yang ikut ber-KB. Mengingat KAT Baduy termasuk yang menutup diri terhadap hal-hal yang berasal dari luar komunitasnya namun secara umum mau menerima perubahan yang sifatnya tidak bertentangan dengan adat.

Hasil penelitian menunjukkan masyarakat KAT Baduy memiliki sikap antusias untuk ber KB, meskipun harus menempuh perjalanan yang cukup lama untuk sampai bisa ke lembaga kesehatan (bidan), dan itu mereka bersedia melakukanya, dan semua itu biasanya mereka lakukan dengan berjalan kaki. Telah tumbuh pemahaman dan kesadaran pada masyarakat Baduy jika KB memberikan manfaat, terutama dalam upaya menjarangkan kelahiran dan juga membatasi jumlah kelahiran. Maka sesuai dengan tujuan pada penelitian ini, dapat disimpulkan hal-hal sebagai berikut:

Karakteristik akseptor KAT Baduy umumnya memiliki jumlah anak paling banyak empat orang berarti sebenarnya masyarakat disana tidak termasuk dalam golongan "keluarga besar". Pekerjaan kecenderungan para kaum wanita (istri) dalam mencari pendapatan tambahan dengan melakukan kegiatan menenun. Jarak rumah tempat tinggal responden ke klinik kesehatan (klinik bidan atau puskesmas) umumnya berjarak 2 jam perjalanan kaki. Jenis alat kontrasepsi yang digunakan mayoritas suntik.

Terdapat korelasi yang positif antara karakteristik komunikan (adopter/akseptor KB) dengan efektifitas penerimaan inovasi. Meskipun hubungan itu terbilang lemah. Selain itu terdapat korelasi yang positif, antara jenis saluran komunikasi dengan efektifitas penerimaan inovasi mempunyai hubungan yang "cukup kuat". Ciri dan jenis inovasi menunjukkan bahwa tidak terdapat hubungan yang signifikan antara jenis dan ciri inovasi dengan efektifitas penerimaan inovasi.

Hubungan karakteristik dengan penerimaan inovasi KB di KAT Baduy. Masyarakat KAT Baduy lebih meyakini menggunakan alat kontra sepsi "suntik", sangat boleh jadi alat kontrasepsi ini relatif lebih praktis dan waktunya agak lama (sebulan sekali), dan tidak menutup kemungkinan alat kontrasepsi pada masyarakat ini, dianggap tidak banyak ditemukan afek negatifnya.

Masyarakat KAT Baduy ternyata mengenal ber KB ada yang sudah lama yaitu antara 10-12 tahun, fenomena ini sebenarnya cukup menarik untuk ditelaah para petugas dinas kesehatan dan khusunya petugas PLKB, dan peneliti lain.

Dalam memutuskan untuk ber KB masyarakat KAT Baduy relatif cepat, karena kalau kita cermati untuk setingkat masyarakat disana yang relatif kurang banyak informasi yang masuk, sementara disisi lain pengaruh adat yang kuat.

\section{Daftar Pustaka}

Adimihardja K. 2007. Dinamika Budaya Lokal. Bandung. CV. Indra Prahasta dan Pusat Kajian LBPB.

2000. Orang Baduy di Banten Selatan: Manusia Air Pemelihara Sungai, Jakarta. Jurnal Antropologi Indonesia. FISIP UI. Halaman 57.

Anonimous. 1999. Keppres No. 111/1999 Tentang Pembinaan Kesejahteraan Sosial Komunitas Adat Terpencil. Jakarta: Direktorat Pembinaan Komunitas Adat Terpencil. Departemen Sosial RI.

2001. Perda No. 31 Tahun 2001 tentang Rencana Tata Ruang Wilayah Kabupaten Lebak.

Devi S, Fatchiya SA, Susanto D. 2016. Kapasitas Kader dalam Penyuluhan. Bogor (ID): Jurnal Penyuluhan 12 (2): 144-156.

Dimyati I. 2016. Perilaku Komunikasi Tenaga Kesehatan di Komunitas Adat Baduy. Disertasi. Program Pascasarjana Unpad, Bandung.

Erlina MD, Kurniasari N. 2006. Peningkatan Pengetahuan Siswa SUPM Kota Tegal (Jawa Tengah) Melalui Penyebaran Informasi Tentang Transportasi Udang Hidup Sistem Kerting 
Menggunakan Media Film Bingkai Bersuara. Jurnal Penyuluhan. Vol. 2. No. 1. Halaman 18. . 2001. Perda No. 32 Tahun 2001 tentang

Perlindungan atas Hak Ulayat Masyarakat Baduy. 2002. Keputusan Bupati Lebak No. 590 / Kep. 233 / Huk / 2002 tentang Penetapan BatasBatas Detail Tanah Ulayat Masyarakat Adat Baduy di Desa Kanekes Kecamatan Leuwidamar Kabupaten Lebak.

Garna JK. 1993a. Masyarakat Baduy di Banten. , dalam Koentjaraningrat (ed) Masyarakat Terasing di Indonesia. Jakarta: Depsos RI, Dewan Nasional Indonesia untuk Kesejahteraan Sosial, dan Gramedia.

1993b. Orang Baduy di Jawa: Sebuah Studi Kasus Mengenai Adaptasi Suku Asli Terhadap Pembangunan., dalam Lim Teck Ghee dan Alberto G. Gomes (peny). Suku Asli dan Pembangunan di Asia Tenggara. Jakarta: Yayasan Obor Indonesia.

. 1994. Masyarakat Tradisional Banten dan Upaya Pelestarian Nilai-Nilai Budaya. Serang. Makalah pada Seminar Puncak-Puncak Perkembangan Warisan Budaya.

Koentjaraningrat. 1990. Sejarah Teori Antropologi II. Universitas Indonesia Press. Jakarta

Kurnia A, Sihabudin A, 2010. Saatnya Baduy Bicara. Diterbitkan atas kerjasama Penerbit Bumi Aksara, dan Universitas Sultan ageng Tirtayasa. Jakarta.

Purnomohadi S, 1985. "Sistem Interaksi SosialEkonomi dan Pengelolaan Sumberdaya Alam Oleh Masyarakat Badyi di Desa Kanekes, Banten Selatan." Tesis. Bogor: Pascasarjana Jurusan Pengelolaan Sumber Daya Alam. Institut Pertanian Bogor.

Rogers EM, Shoemaker FF. 1971. Communication of Innovations. A Cross-Cultural Approach. The Free Press. New York.

Keluarga Berencana di Kota Palembang, Provinsi Sumatera Selatan. Jurnal Penyuluhan, September 2016 Vol. 12 No. 2

Sihabudin A. 2015. Kebutuhan Keluarga Komunitas Adat Baduy. Penerbit Untirta Press. Bekerjasama dengan PT. Kemitraan Energi Industri. Serang.

Simanjuntak M. 2014. Karakteristik Sosial Demografi dan Faktor Pendorong Peningkatan

Kinerja Kader Posyandu. Jurnal Penyuluhan, Maret 2014 Vol. 10 No. 1
Singarimbun M, Effendi S, (Ed). 2006. Metode Penelitian Survai. Edisi Revisi. Jakarta: Penerbit Pustaka LP3ES. 